\title{
Research
}

\section{Social-ecological Resilience of a Nuosu Community-linked Watershed, Southwest Sichuan, China}

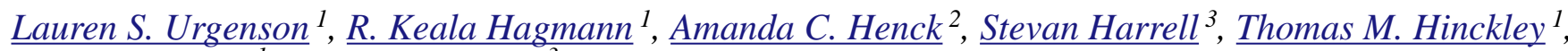 \\ $\underline{\text { Sara Jo Shepler }}^{1}$, Barbara L. Grub ${ }^{3}$, and Philip M. Chi
}

\begin{abstract}
Farmers of the Nuosu Yi ethnic group in the Upper Baiwu watershed report reductions in the availability of local forest resources. A team of interdisciplinary scientists worked in partnership with this community to assess the type and extent of social-ecological change in the watershed and to identify key drivers of those changes. Here, we combine a framework for institutional analysis with resilience concepts to assess system dynamics and interactions among resource users, resources, and institutions over the past century. The current state of this system reflects a legacy of past responses to institutional disturbances initiated at the larger, national system scale. Beginning with the Communist Revolution in 1957 and continuing through the next two decades, centralized forest regulations imposed a mismatch between the scale of management and the scale of the ecological processes being managed. A newly implemented forest property rights policy is shifting greater control over the management of forest resources to individuals in rural communities. Collective forest users will be allowed to manage commodity forests for profit through the transfer of long-term leases to private contractors. Villagers are seeking guidance on how to develop sustainable and resilient forest management practices under the new policy, a responsibility returned to them after half a century and with less abundant and fewer natural resources, a larger and aggregated population, and greater influence from external forces. We assess the watershed's current state in light of the past and identify future opportunities to strengthen local institutions for governance of forest resources.
\end{abstract}

Key Words: China; forests; institutions; Nuosu; resilience; Sichuan; Yi

\section{INTRODUCTION}

Dramatic shifts in China's forest policies over the past century have led to substantial changes in the availability of forest products and ecosystem services as well as the institutions governing their use (Hyde et al. 2003, Xu et al. 2004, Weyerhaeuser et al. 2005). Rapid and contradictory changes in institutions for forest governance have resulted in uncertainty and limitations on local control (Miao and West 2004). These changes have had particularly strong effects on rural communities that are directly dependent on local resources and have few alternatives if local ecological systems fail to support them (Xu and Ribot 2004, Melick et al. 2007). Although relationships between national forest policy changes and local forest resource management in rural subsistence communities within China are not well documented (but see $\mathrm{Xu}$ et al. 2005, 2006, Melick et al. 2007, Xu and Melick 2007, Liu 2009), the cumulative effects of these policy changes, i.e., natural resource degradation and increased socioeconomic pressure, may further jeopardize marginalized communities.

A new Collective Forestry Reform (CFR) policy, introduced in June 2008, separates forestlands into ecological reserves and commodity forests and allows collective forest users to manage commodity forests for profit through long-term leases to private contractors (Zhonggong Zhongyang 2008, Dai et al. 2009). Official goals of the policy are to give local people an ownership stake in forests and to stimulate rural income without compromising common-pool resources (State Forestry Administration, Beijing, Nov. 6, personal communication). Formerly top- 
down regulations are being loosened to allow contractors to manage forests. Contractor management under the new policy is likely to result in conflicts between communities dependent on forests for subsistence and contractors managing the forests for financial profit. Both community member and contractor interests are liable to conflict with ecosystem services or other public benefits (Hoang 2009). This latest policy shift emphasizes the need to understand how communitylinked ecosystems are affected by disturbance events such as the upcoming change in land use. Increased understanding, in turn, may influence community and official decision making about how to allocate rights to forest products under the new policy, decisions that will have long-term ramifications for the resilience of the forests and the communities that use them.

Our team of ecologists, anthropologists, and geologists has conducted more than nine years of research on the social-ecological dynamics of the communities, forests, pastures, and streams of the Upper Baiwu watershed, Liangshan Yi Autonomous Prefecture, southwestern Sichuan Province. The 1100 farmers of the Nuosu Yi ethnic group (Harrell 2001, Hill 2001, Mgebbu 2003) who live in the watershed report reductions in the availability of local forest goods and ecosystem services, e.g., fuel wood, flood regulation, and livestock grazing areas, and question whether the local environment will continue to provide the resources required to meet their needs. Their goal and ours is to determine how best to build and maintain a system of sustainable and resilient management practices for local forests under the new national forest policy. Here, we combine community members' oral historical accounts with the results of our scientific investigations to describe the type and extent of social-ecological changes over the last century, identify key drivers of those changes, and suggest how a combination of traditional ecological knowledge and scientific data can help meet our common goal.

We develop an analytical framework combining a three-part model of social-ecological system organization with a temporal model derived from resilience theory to assess historic changes in watershed dynamics. Within this framework, our analysis depends on the substantial scholarship in the field of institutional analysis, which has identified a set of conditions under which users are more likely to sustainably govern the resource systems upon which they depend (Ostrom 1990, Agrawal 2001, Anderies et al. 2004). Our framework organizes the social-ecological system of the Upper Baiwu Valley into three elements: resources, resource users, and institutions. Resources include forests, pastures, and watercourses. Resource users are the local human population. Institutions are the informal and formal rules that incentivize resource users' behaviors. Throughout this study, we emphasize the role of institutions as key controlling variables in this watershed.

We first describe the state of the local socialecological system in 2008-2009. We then present a historical sequence of changing system states since 1920. For each historical stage, we employ resilience concepts to understand the processes of change and we evaluate the institutions against the design principles set out by Ostrom (1990) for sustainable common-property management regimes (Anderies et al. 2004). Resilience concepts include ecosystem resilience, slow variable change, crossscale interaction, and the adaptive cycle (Levin et al. 1998, Scheffer et al. 2002, Gunderson 2003, Abel 2006, Liu et al. 2007). We conclude with suggestions of how our analysis may help us to cooperate with local residents and officials in promoting a more sustainable and resilient socialecological system.

\section{METHODS}

\section{Study area}

The Upper Baiwu watershed (approximately 56 $\mathrm{km}^{2}$ ) lies in the north-central part of Yanyuan County, Liangshan Yi Autonomous Prefecture, Sichuan Province, China $\left(27^{\circ} 41^{\prime} \mathrm{N}\right.$ and $101^{\circ} 25^{\prime}$ E; Fig. 1). We intensively investigated two subwatersheds within the valley. The Apiladda watershed occupies approximately $32 \mathrm{~km}^{2}$ in the middle reaches of Gangou Creek. It rises several kilometers to the north in the Zala Mountains, flows through the small village of Gangou at the head of Apiladda, continues for $5 \mathrm{~km}$ along the narrow alluvial floodplain of Apiladda proper, and opens out near the villages of Yangjuan and Pianshui into the broader alluvial plain of Yiejuoladda (Fig. 2). The smaller Laizigou watershed (approximately 1 $\mathrm{km}^{2}$ ) is centered along a stream that rises approximately $2 \mathrm{~km}$ north of the main Yiejuoladda floodplain and flows through a narrow valley, ending where the creek disappears underground into 
Fig. 1. Location of the Baiwu Valley in Yanyuan County, Liangshan Autonomous Prefecture, Sichuan Province.

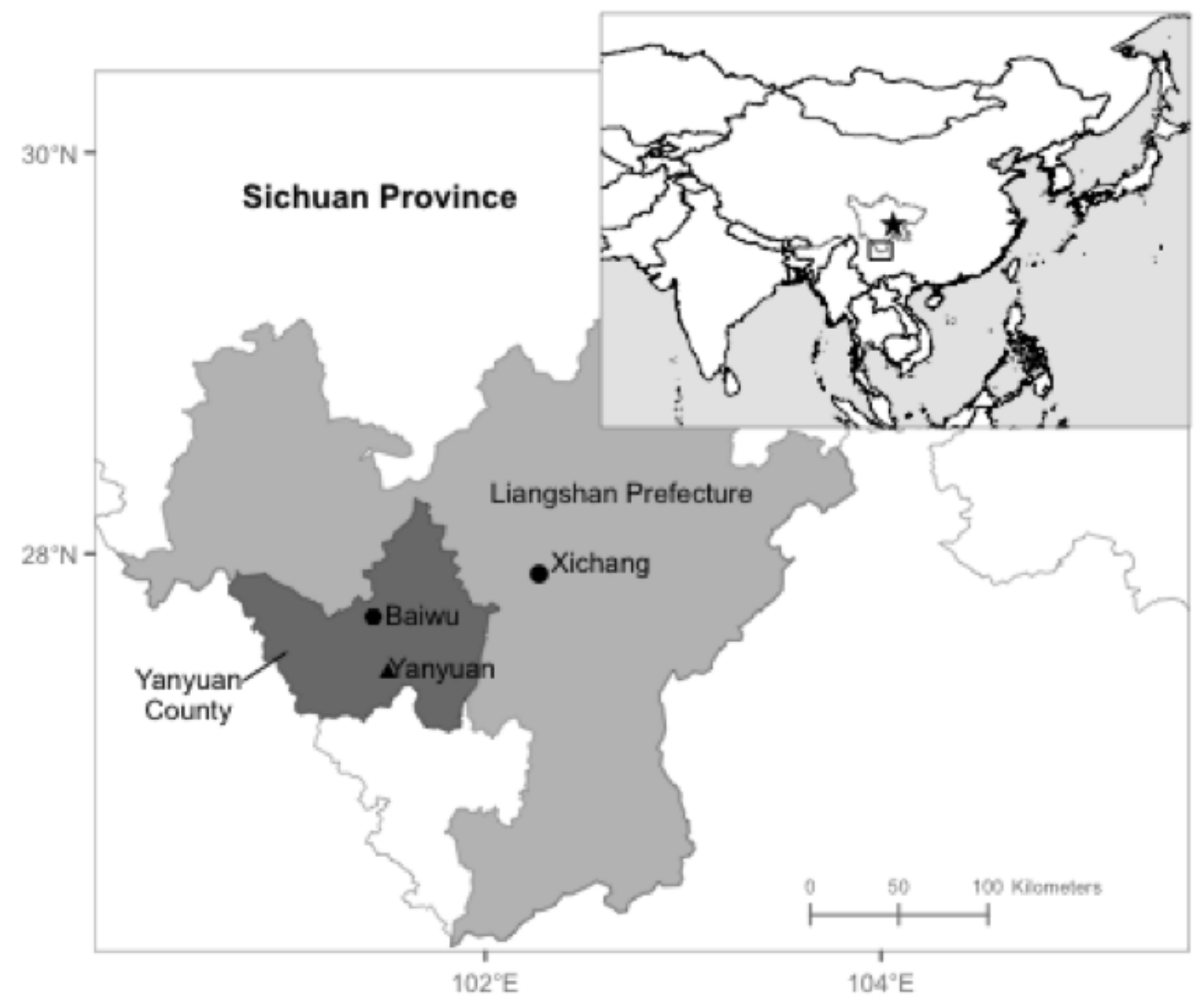

karst caves just north of the village of Pianshui. The floodplain of Apiladda and Yiejuoladda lies at an elevation of $2500-2650 \mathrm{~m}$, with the surrounding forested hills rising to $3700 \mathrm{~m}$. The climate is characterized by mild, wet summers that receive approximately $70 \%$ of the $850 \mathrm{~mm}$ of annual precipitation (Yanyuan County 1984) falling from June through September, as well as cold, dry, windy winters with freezing nights and average daily temperatures hovering around freezing.
All 1100 inhabitants of the villages of Yangjuan, Pianshui, Gangou, and Zhuchang are members of the Nuosu ethnic group, a subgroup of the Yi, one of China's 56 officially recognized nationalities. Nuosu have lived in this area since the middle to late 1700s, gradually displacing the earlier Prmi inhabitants. 
Fig. 2. The Upper Baiwu watershed, 2001 ASTER satellite image. Watershed boundaries are shown in green; watershed names are in bright blue; extent of village housing is in gray shading; village names are in black; geographic locations referred to in the text are in brown.

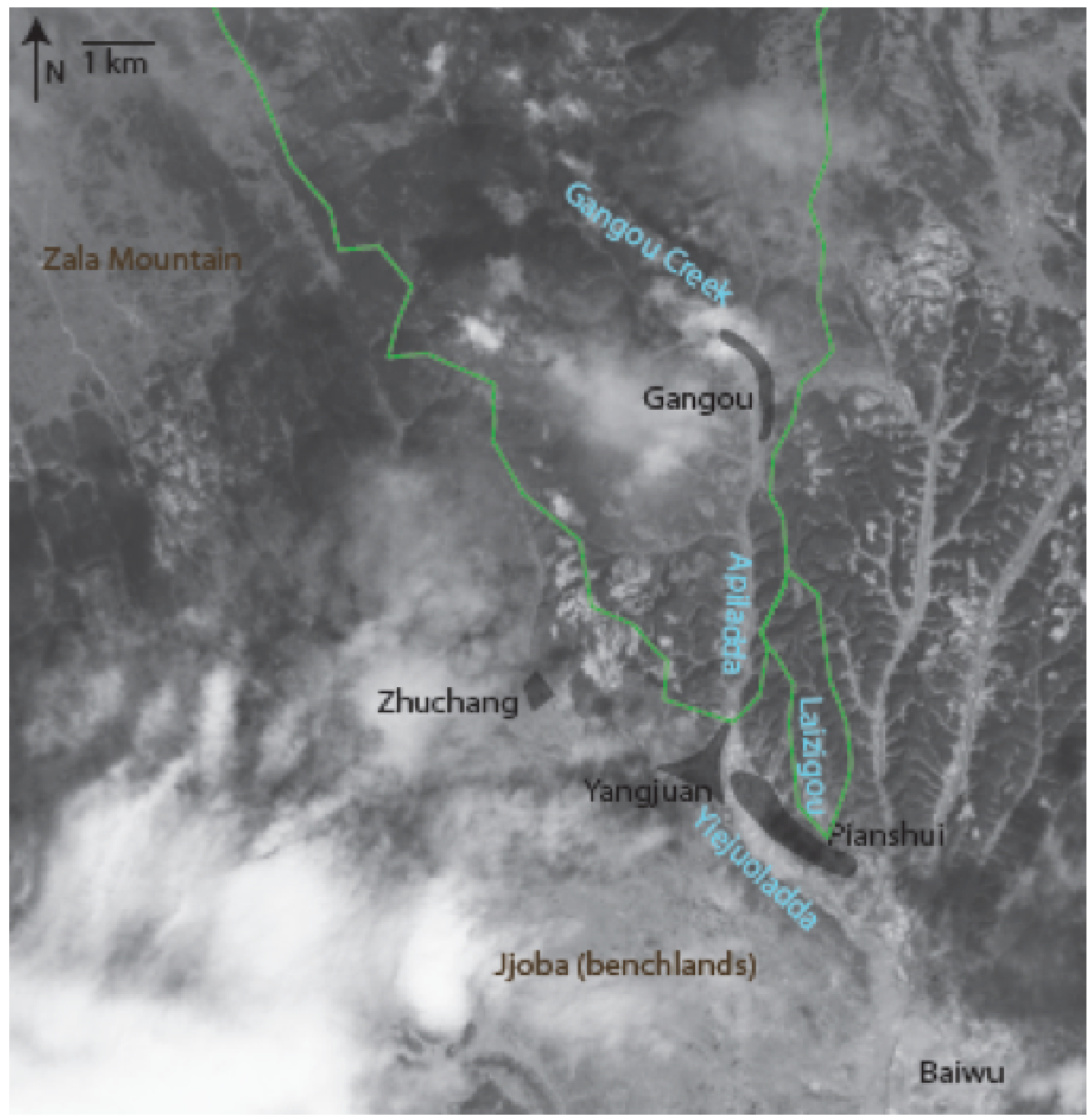




\section{Data collection}

Our data and analysis are derived from more than nine years of ethnographic and historical interviews, guided walks, community mapping, and collection of quantitative and qualitative data on the forests, pastures, and streams in the watershed. Every year since 2000, we conducted oral interviews covering the history of natural resource use and associated ecosystem change; native names for places, plants, animals, soils, and ecotypes; proverbs in the Nuosu language explaining the behavior of ecosystems and prescribing the proper use and care of resources; household firewood use; and livestock production, including herding culture, pasture conditions, livestock censuses, and participant observation in herding and other care of animals.

Geomorphological studies of the streams have consisted of cross-section surveys, pebble counts, descriptions of river cut stratigraphy, and terrace surface and channel thalweg maps. We have used both aerial and ground photography to observe changes in vegetation and river channel morphology.

We conducted three studies of the forest. The first was a structural and compositional inventory of overstory and understory components of $1220 \times 20$ $\mathrm{m}^{2}$ plots located within pine-dominated forest stands (Chi 2004). The second was a survey of the structure and condition of forests across the Apiladda and Laizigou sub-watersheds, including site characteristics (elevation, slope, slope position, aspect, dominant overstory and understory species) and indicators of human use (branch cutting, slashing, bare ground, tree stumps, coarse woody debris) of 83 data points gathered during guided walks with local community members. The third was an assessment of the effects of extensive crown removal on tree growth (diameter, height, basal area increment) by comparing cut and uncut Pinus yunnanensis growing within $50 \mathrm{~m}$ of each other on similar sites.

We supplemented biophysical and ethnographic field data with examination of declassified Corona satellite imagery acquired at $1.8-7.6-\mathrm{m}$ resolution between 1961 and 1979 (United States Geological Survey 1998). Comparing photos of forest cover and stream courses with oral accounts of changes in forest cover, land use, and hydrology, as well as discussion of the aerial imagery with local residents, has allowed us to piece together a coherent picture of land, water, and vegetation changes for the past century.

\section{RESULTS}

\section{Current system state}

\section{Resource users}

The resident community of the Baiwu Valley includes approximately 1100 people, with approximately 450 each in the two major villages of Yangjuan and Pianshui and approximately 100 each in the small satellite villages of Zhuchang and Gangou. All speak Nuosu as their first language; most speak Chinese as a second language with various degrees of proficiency. Residents of the watershed are closely dependent on local natural resources for their livelihoods. They draw subsistence from a combination of farming staple crops (potatoes, corn, buckwheat, and oats), raising livestock (sheep, goats, cattle, pigs, chickens, horses, and yaks), and harvesting forest products (wood for fuel; leafy branches and forest litter for lining stables and protecting walls against rainstorms; pine stems for construction; and herbs, berries, and fungi for food and medicine). In recent years, they have supplemented this with increasing income from commercial crops such as apples, hybrid corn, and Sichuan peppercorn (huajiao, Zanthoxylum piperitum); from the sale of livestock products; and from labor migration to China's cities to work in factory, service, and construction jobs.

The Nuosu culture of the Baiwu Valley is rich in traditional ecological knowledge (TEK). Traditional elements conceptualize the ecosystem and the kinship system as parallel structures that must be kept in balance and in harmony to ensure the continuity of both systems through the processes of production and reproduction. Increased contact with the outside world through the Chinese revolution, globalization, formal Chinese-language education, exposure to mass media, and widespread labor migration has caused much of this TEK to become the exclusive property of older generations. Young people generally devote much of their attention to learning the Chinese language and Chinese popular culture. However, community members participate daily in subsistence labor beginning in middle childhood. This labor serves to 
Table 1. Characteristics of the pine-dominated and mixed forest community types. The mixed communities have larger and older trees, greater basal area, more overstory diversity, and less human use.

\begin{tabular}{|c|c|c|}
\hline Forest characteristic & Pine-dominated forest & Mixed forest \\
\hline Location & $\begin{array}{l}\text { Laizigou and southern Apiladda } \\
\text { watersheds }\end{array}$ & Northern and western Apiladda watershed \\
\hline Distance from villages & Near & Far \\
\hline Elevation range $(\mathrm{m})$ & $2550-2750$ & $2600-3050$ \\
\hline Overstory in sunny locations & Pinus yunnanensis & $\begin{array}{l}\text { Pinus yunnanensis with sub-dominant } \\
\text { Alnus ferdinani-obergii }\end{array}$ \\
\hline Overstory in shady locations & Pinus yunnanensis & $\begin{array}{l}\text { Co-dominant Alnus ferdinani-obergii, } \\
\text { Quercus spp., Pinus yunnanensis, Pinus } \\
\text { armandii, and Rhododendron spp. }\end{array}$ \\
\hline Range of basal area $\left(\mathrm{m}^{2} / \mathrm{h}\right)$ & $2.0-29.0$ & $18.4-48.2$ \\
\hline Median basal area $\left(\mathrm{m}^{2} / \mathrm{h}\right)$ & 13.2 & 38.6 \\
\hline $\begin{array}{l}\text { Median age of cored Pinus } \\
\text { yunnanensis (years) }\end{array}$ & 31.7 & 44.2 \\
\hline Most common understory species & $\begin{array}{l}\text { Rhododendron spp., Lyonia ovalifolia, } \\
\text { Corylus spp., Rosa spp., Viburnum spp. }\end{array}$ & $\begin{array}{c}\text { Rhododendron spp., Lyonia ovalifolia, } \\
\text { Quercus spp., Pinus yunnanensis., } \\
\text { Pteridium spp., Rosa spp., bamboo }\end{array}$ \\
\hline Species gathered for firewood & Pinus yunnanensis & Alnus ferdinani-obergii, Quercus spp. \\
\hline Species gathered for construction & Pinus yunnanensis & Pinus yunnanensis, Pinus armandii \\
\hline
\end{tabular}

maintain practical knowledge of farming, livestock, and forestry practices. Many people of all ages, including schoolteachers, profess commitment to preservation and enhancement of local culture and traditional knowledge.

\section{Resources}

\section{Forests}

There are four key attributes of local forests. The forests comprise two distinct forest types, with widespread dominance by Pinus yunnanensis (Yunnan pine) in the lower elevation areas closest to villages, transitioning to mixed forests of conifers and hardwoods to the north and west in the headwaters of the watershed at higher elevations (Table 1, Fig. 3A). The forests consist of relatively young trees $<57$ years old (Fig. 3B). There is extensive human use of the forests for forest products. Finally, there is apparent interaction between human effects (e.g., branch cutting, wood removal, livestock grazing) and forest structure (Chi 2004; Fig. 4).

In the lower watershed, north of Pianshui village and between the valley of Laizigou, the main alluvial valley of Apiladda, and Yangjuan village (see Fig. 2), the forest on the predominant sandstone substrate at $2550-2750 \mathrm{~m}$ elevation is largely homogenous in structure and function on all aspects and slope positions, with a single-story canopy of P. yunnanensis. The area is heavily trafficked and used for gathering wood. Meadows among these forests are kept bare by frequent grazing. Villagers of Pianshui depend on this zone for wood and thus 
Fig. 3. Distribution of forest types, maximum tree ages, and stand basal areas in the Apiladda and Laizigou watersheds. (A) A rough approximation of the distribution of forest cover in the Apiladda and Laizigou watersheds, extrapolated from point data for 83 points collected during GPS surveys conducted along well-used forest and meadow trails. Shaded areas indicate variation in dominant and sub-dominant canopy species throughout the watershed: PIYU = Yunnan pine (Pinus yunnanensis); PIAR = Chinese white pine (Pinus armandii); ALFE = Alnus ferdinani-obergii; mixed as sub-dominant $=$ PIYU, alder, or oak; mixed as dominant = PIAR, alder, oak, or rhododendron. Forest cover transitions from dry, opencanopy stands of stunted Yunnan pine to wet, closed-canopy, mixed conifer and hardwood forests with increased distance from villages and with increasing elevation and latitude in the watershed. Patterns in species distribution, tree age, and stand basal area agree with local accounts of periodic intensive harvests, as well as studies of grazing and chronic, low-intensity biomass removal; however, geophysical influences on forest cover have not been quantitatively isolated from anthropogenic influences. (B) The ages of the largest trees (PIYU or PIAR) sampled at the points indicated using an increment corer at breast height. (C) Basal area of trees, recorded in 2002 using tree counts and size measurements in 400- $\mathrm{m}^{2}$ plots, and in 2008 using a keyhole prism. The circle size indicates relative basal area as a percentage of the largest recorded; specific basal areas are shown in tree area per ground area $\left(\mathrm{m}^{2} / \mathrm{ha}\right)$. Maximum tree age $(\mathrm{B})$ and basal area $(\mathrm{C})$ increase with elevation and distance from population centers.
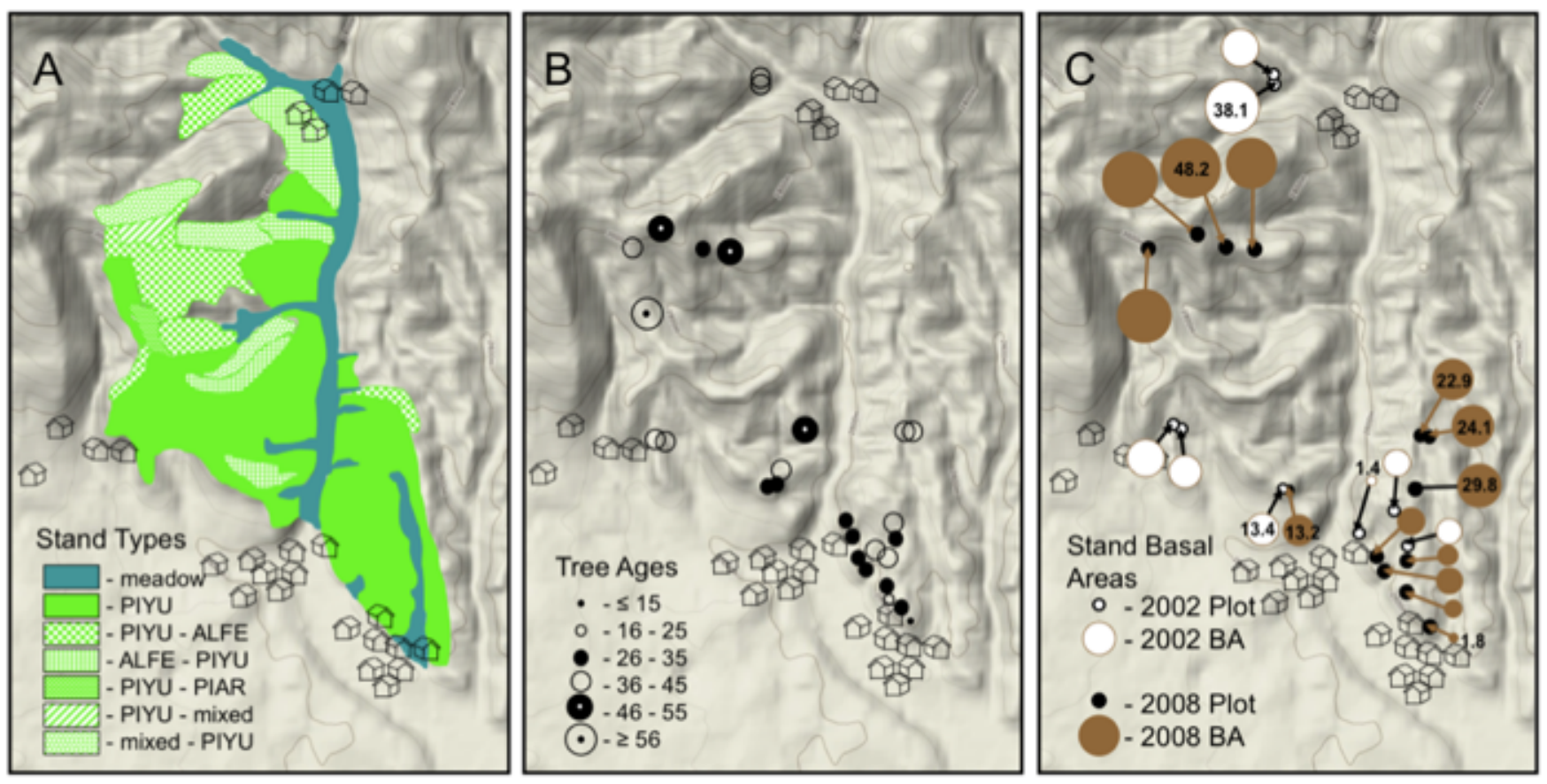

burn mostly pine branches for cooking and heating, even though it is lower density than oak or alder (Diane Tsao and Thomas Hinckley, unpublished data) and is considered a less desirable firewood species. Stand basal areas in this forest type ranged from $<1.5 \mathrm{~m}^{2} /$ ha in heavily used areas close to the villages to $29.8 \mathrm{~m}^{2} / \mathrm{ha}$ in a hilltop stand on the ridge between the Laizigou and Apiladda watersheds (median $=13.2 \mathrm{~m}^{2} / \mathrm{ha}, N=19$; Fig. 3C). Ring count at breast height placed tree ages between 12 and 52 years $($ mean $=31.7$ years, $N=38)$.

Also in the lower watershed, $P$. yunnanensis demonstrates strong growth recovery following 
Fig. 4. View of part of the Laizigou watershed in the dry season, showing heavily eroded hillsides, braided animal trails, and a sparse overstory of Pinus yunnanensis on south-facing slopes and scrub vegetation on north-facing slopes. Photo: Shermi Liang.

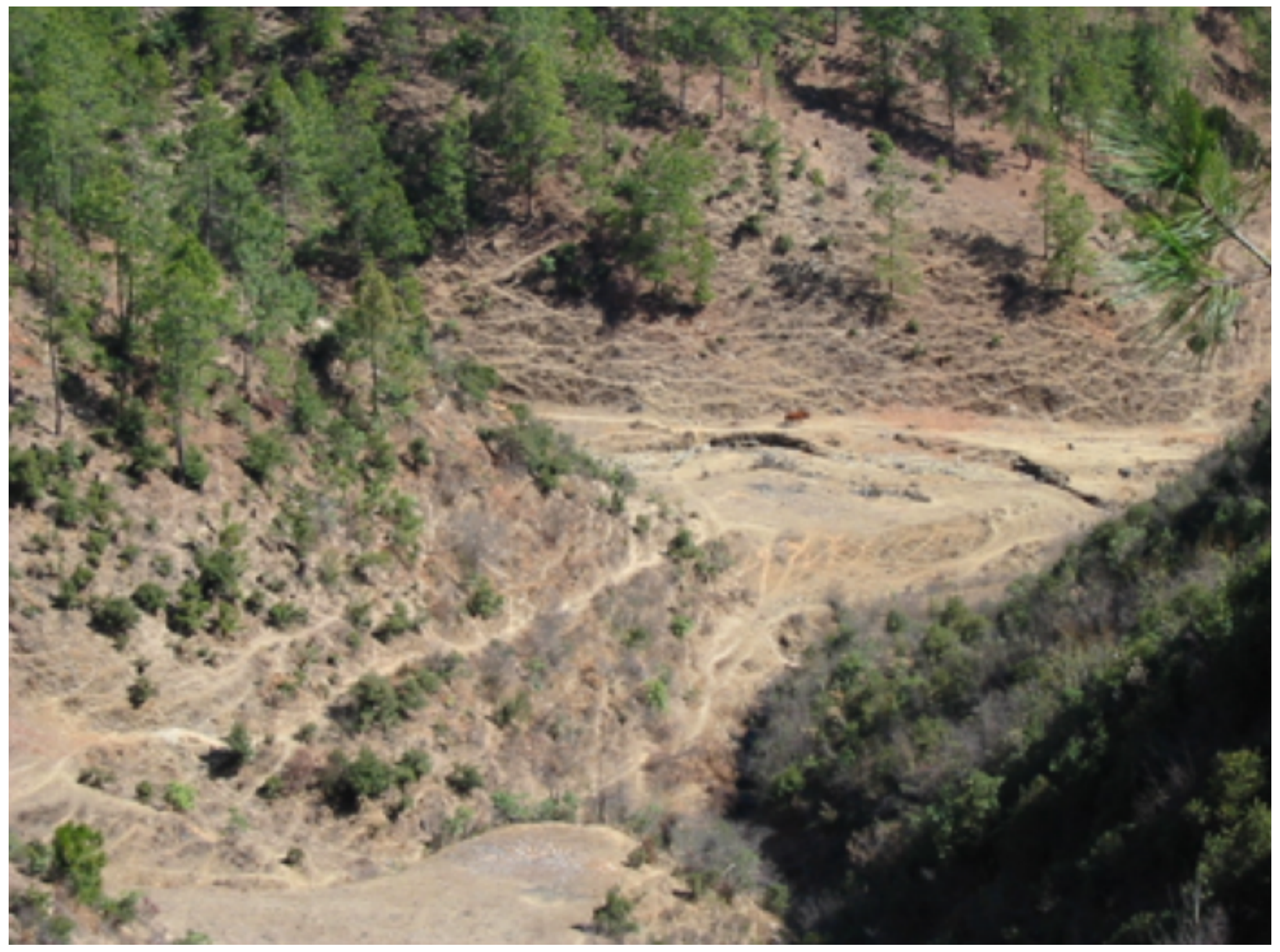

extensive branch cutting. We compared $P$. yunnanensis trees with extensive branch removal to similar, neighboring trees with few or no branches removed ( $N=15$ pairs for comparison). Cut trees exhibited smaller live crowns (mean \pm SE: $36.5 \pm 0.6$ vs. $52.9 \pm 0.9$ percent of total height), smaller diameters (mean \pm SE: $17.7 \pm 0.5$ vs. $21.0 \pm 0.5 \mathrm{~cm}$ ), and shorter heights (mean \pm SE: $8.7 \pm 0.3$ vs. 10.6 $\pm 0.3 \mathrm{~m})$. However, in spite of these size differences, the treatment groups exhibited highly similar diameter growth rates over the last five years (expressed in terms of average basal area increment over the last five years: $845 \pm 49$ vs. $854 \pm 48 \mathrm{~mm}^{2}$ ). These data suggest that $P$. yunnanensis demonstrates both recovery and mechanisms to compensate for crown loss.

In the headwater areas to the west of the Apiladda floodplain, as well as the Xingou watershed north of the head of Laizigou, at 2750 - 3050 m elevation, forests contain greater species diversity, older trees, and higher basal areas than the P. yunnanensis forest type (Table 1). P. yunnanensis still dominates yang slopes (southeast- to west-facing slopes) and exposed positions on hilltops, but the trees are larger and older here than in the Pianshui forests (Fig. 3B). On yin slopes (northwest- to east-facing slopes), a mixture of $P$. yunnanensis, Alnus ferdinani-obergii, 
Fig. 5. Number of stumps per hectare plotted against basal area for $20 \times 20 \mathrm{~m}^{2}$ plots (2002) or $20 \mathrm{~m}$ diameter circular plots (2008). High numbers of stumps, reflecting heavy human use, are associated with low basal area per hectare.

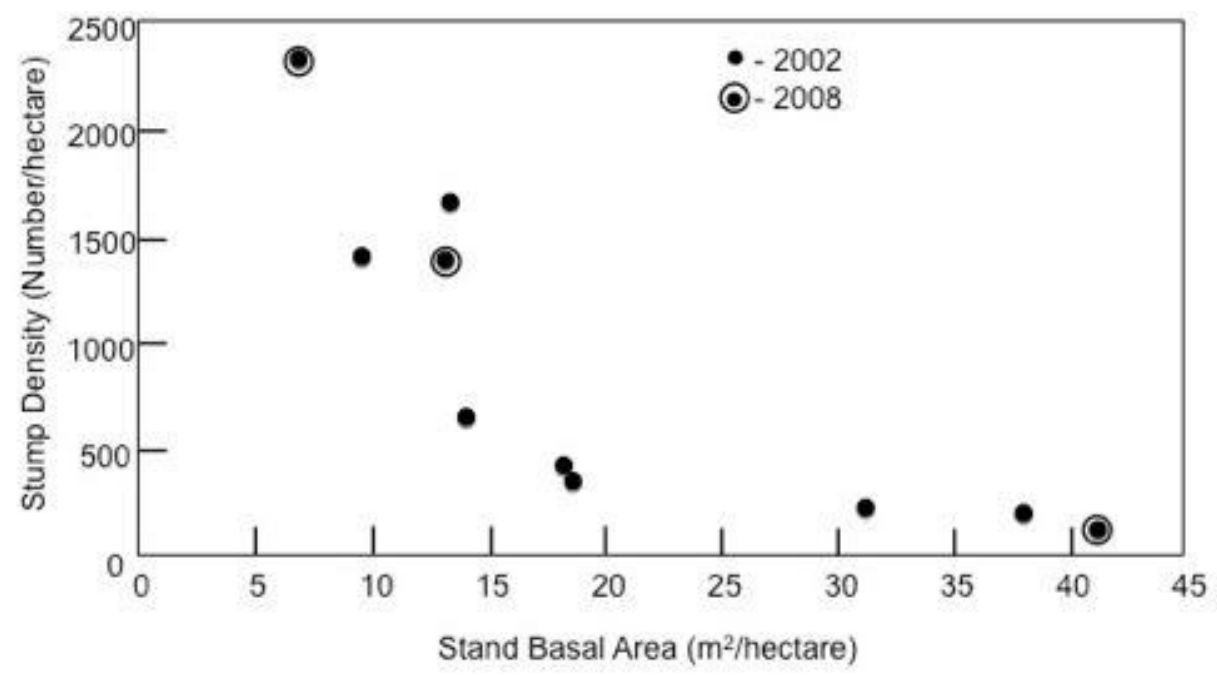

and evergreen Quercus spp. dominates the overstory. On several north-facing slopes, large specimens of Rhododendron form a mid-story to dominant overstory, and at these higher elevations, Pinus armandii is co-dominant. As in the pinedominated area, tree size and stand density (Fig. 3C) vary with distance from the villages and elevation. Stand basal areas range from 18.4 to $48.2 \mathrm{~m}^{2} / \mathrm{ha}$ (median $=38.6, N=6$ ). Ring count at breast height places the oldest tree at approximately 57 years old (mean $=44.2, N=12$ ). Villagers of Yangjuan and Zhuchang have collective rights to these areas and preferentially collect alder or oak for firewood. Pines from this area are still the most desired specimens for construction; their straight trunks are easily worked.

The distribution of the pine-dominant and mixed forest types appears to be associated with both environmental factors, e.g., precipitation and insolation, and the human history of recent use ( $\mathrm{Li}$ and Walker 1986, Jarvis and Liu 1993, Melick et al. 2007). Both within and between forest types, stand basal area increases with distance from trails and villages, as well as with increases in elevation. In contrast, the number of observed stumps decreases with these same factors (Fig. 5). Anthropogenic effects include tree and branch removal, litter removal, livestock grazing, soil compaction, and erosion. Tree removal and grazing may reduce the stand carrying capacity below its potential. Branch removal may reduce tree height and diameter growth. Litter removal, soil compaction, and erosion may reduce site water and nutrient capacities and thus affect productivity. Steep slopes appear to accentuate the effects of people and livestock (Fig. 4).

During our community walks, we observed very few signs of wild fauna. Local people report little evidence of the formerly present macrofauna even in more distant forests. A 9-day expedition in 2004 discovered only ambiguous evidence of wolves. Although bears, red pandas, and wildcats are occasionally reported, there have been no sightings of cougars for at least a generation. Villagers also report that songbirds have diminished in variety and number. 


\section{Pastures}

Livestock are herded twice a day through the narrow Apiladda valley. Large numbers of grazers and browsers, in mingled herds of $>100$ cattle, water buffalo, horses, sheep, goats, and pigs are common. Less mobile herders leave their animals in the valley during the day and return to collect them in the evening. More mobile herders access the numerous side valleys farther up the hillsides to graze animals in areas with more grass. Livestock species separate in search of additional forage; water buffalo and pigs stay closest to the river, horses and cattle graze on the steep hills bordering the valley bottom, and sheep and goats range freely on the hillsides. Often, herders will slash alder and oak to make branches accessible to these animals.

As a result of this constant use, the Upper Baiwu is severely overgrazed, particularly in the readily accessed areas near villages (Fig. 6). Herders must travel farther into the hills to find good grazing. Animals are thin, small, and plagued by recurrent infestations of liver fluke parasites. Few meadow plants reach heights $>3 \mathrm{~cm}$; most flower and go to seed at $<3 \mathrm{~cm}$ in height. Overgrazing is particularly severe during the dry spring months, when the higher elevations are still too cold to allow plant growth.

\section{Watercourses}

Gangou Creek currently is braided near the bottom of the valley (Fig. 6) and transitions up the valley to pool-riffle, step-pool, and cascade channel forms. The channel actively moves in its floodplain and, based on pebble surveys and qualitative analysis of sediment load, seems to be able to carry the sediment it receives. The current state of the river is a concern for villagers, who report increased seasonal flooding, higher flood-level discharges, and fewer fish in the system compared to in the past. According to villagers, the discharge is flashy, with high levels of flood damage to riverbanks through the village in wet months, interspersed with periods in which water barely flows during the dry season. High grazing pressure appears to restrict floodplain forest establishment; riverside vegetation comprises grasses and herbs, with only two trees present in the lower $3 \mathrm{~km}$ of the valley floor. Consequently, large woody debris is largely absent from the stream, potentially decreasing habitat variety (Abbe and Montgomery 1996). The only wood in the stream is in the form of levees positioned to protect terraces from erosion during high river flows.

\section{Institutions}

Regulations governing resource use are highly centralized at the national scale and applied without consideration of local social-ecological conditions (Weyerhaeuser et al. 2005, Trac et al. 2007, Xu and Melick 2007). Two national forest enhancement policies are designed to restore degraded forests and soils (Zhang et al. 2000) but fail to account for community needs. The Natural Forest Protection Program (NFPP) imposes a logging ban in state forests in the upper reaches of the Yangtze and Yellow rivers and has resulted in heavy restrictions on forest cutting. Villagers are allowed to cut branches or take downed wood for firewood but are not allowed to cut whole trees except according to a strict quota system (Xu et al. 2004, Weyerhaeuser et al. 2005, Trac et al. 2007). The County Forestry Bureau assigns a yearly quota of timber to the Baiwu Township government, which allocates the quota to the individual villages. Households then must apply for a portion of this quota. The Sloping Land Conversion Program (SLCP; also called Grain-forGreen) incorrectly identifies highly sloping land and fails to incorporate sufficient short- and long-term incentives to ensure success (Trac et al 2007). The consequences of these regulations include frequent rule infractions and a mismatch between national policy prescriptions and local activities (Cumming et al. 2006).

Community members report confusion over shifting rules, boundary demarcation, and local tenure rights in the watershed. Forests more distant from the villages were called national forest or government forest until 2008, and are now referred to as ecological reserve forest. Woodcutting is nominally forbidden in these areas, but still does occur. Some of the forests closer to the villages are owned by Villager Small Groups, each comprising approximately 50 households, and are managed as common-pool resources. In these forests, members of the managing groups are allowed to cut branches for firewood and to take downed wood. Three small hills to the north of Pianshui village have been managed by three village families as private contractors since 1983; they allow others to cut wood on their land only selectively and by permission. 
Fig. 6. Valley floor of part of the Apiladda watershed in 2008, showing the braided stream course, eroded stream terraces, lack of trees, presences of grazing animals, and newly installed fencing to protect a poplar plantation.

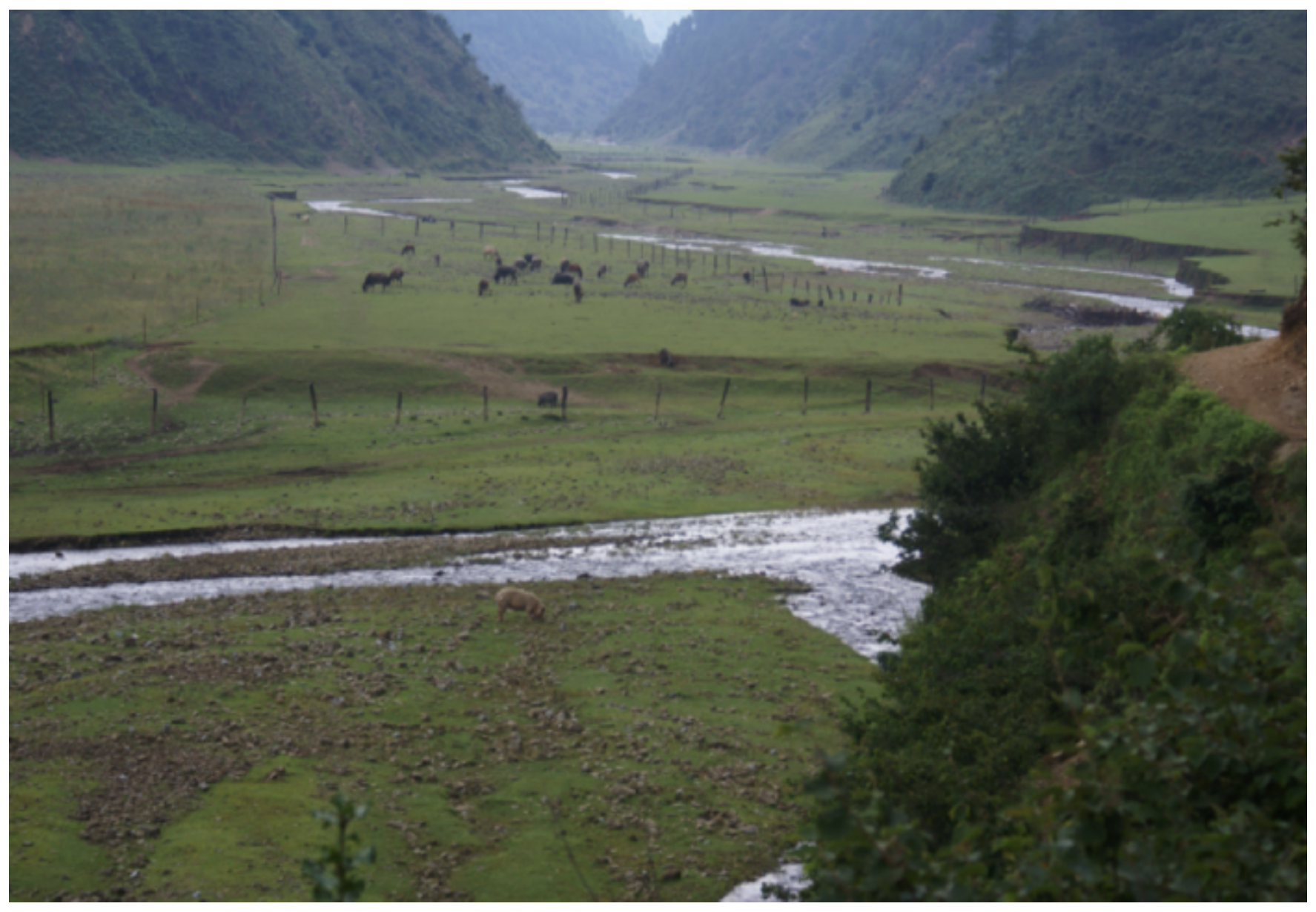

Enforcement of forest use regulations, officially the responsibility of the Township Forest Office, is sporadic. Unofficially, three forest wardens from adjacent villages perform day-to-day patrols with nominal compensation from a collection taken up from Villager Small Group member households. The wardens have no authority to arrest or levy fines, but they monitor forest use and mediate resource disputes informally.

The 2008 CFR policy (Zhonggong Zhongyang 2008) may result in rights to collective forests being transferred to outside contractors. In 2009, one parcel of land was leased to a village official for less than the stated minimum value (120 yuan/mu).
Three of the four villager small groups decided not to entertain offers for lease of their forests on the grounds that their livelihood might be compromised for small and short-term monetary gain. A fourth small group was still considering an offer from an outside corporation in November 2009.

Current institutional arrangements do not adhere to Ostrom's (1990) design principles. Although membership of the appropriating user group is clearly defined, boundaries are not stable and tenure and appropriation rights are unclear, thus principle 1 is only partially supported. Failure of the rules to account for local resource conditions and community needs violates principle 2. Total 
concentration of policy decisions at the national level, without linking to lower system scales violates principles 3 and 8 . Local forest monitors are accountable to the resource users, but their monitoring is sporadic; and township officials with legal enforcement rights are not accountable to resource users and their enforcement is erratic, resulting in partial support of principle 4 and violation of principle 5. Although resource users resolve conflicts among themselves through informal discussion and mediation, there are no consistent formal rules, and users do not have a means of resolving conflicts with township officials, thus leading to only partial support of principle 6. Finally, the lack of local involvement and use of local knowledge and needs in policy development completely violates principle 7 .

\section{History of the Upper Baiwu: cross-scale interactions over more than two adaptive cycles}

Institutional changes at the national scale have been key drivers of ecosystem and social dynamics in the watershed. Social-ecological changes have occurred in the Upper Baiwu watershed over time, and the current state of the ecosystem is partly a legacy of the past (Table 3, Figs. 7 and 8 ). We provide a historical summary of key changes in the watershed from 1920 to the present (Table 3). We also illustrate the shifting panarchies of adaptive cycles over three time periods and extending one scale above the system of interest (national) and one below (family or agricultural collective; Fig. 7). These time periods constitute two turns of the adaptive cycle, with a possible third about to start: cycle I (19201956), cycle II (1961-2008), and cycle III (2008 onward). The third cycle is perhaps beginning, as the present policy change may lead to another regime shift of uncertain nature. Key changes have occurred in resources, resource users, and institutions in each phase of adaptive cycles I and II (Fig. 8).

\section{Cycle I, r phase, 1920-1957}

\section{Resource users}

This period begins when the Nuosu people first moved from dispersed dwellings in the mountains, where they had lived since the 1700s, to the jjoba benchlands southwest of the current village sites. There were no villages at this time. The commoner Mgebbu clan and its affines, who are now the core of Yangjuan, were subjects of Loho and Lomu aristocratic clans. Both the aristocrats and commoners owned serfs and slaves.

Local communities were relatively autonomous from Chinese bureaucratic authorities. Even after the Communist takeover in 1949, Nuosu continued with their patterns of residence and resource use and their clan- and caste-based political organization. Descriptions given by elders suggest that the system was in an $r$ phase of the adaptive cycle (Table 3, Fig. 7). Human population was low, though perhaps increasing slowly. In 1957, the population of the area was probably between 200 and 300 people; there is no indication that levels of consumption were growing.

\section{Resources}

Forests

During this period, the majority of the uplands were forested, but considerable patches within the mountains, particularly on ridges and south-facing slopes, were cleared for swidden agriculture and either allowed to regenerate every 10-20 years or maintained as pasture (Fig. 9). Local people recall that in the mid-20th century, diverse coniferous and broadleaf forests hosted a variety of flora and fauna. In addition to Pinus spp., Alnus spp., Rhododendron spp., and Quercus spp., common trees included Salix spp., several Populus spp., a wild Prunus sp., and a wild Litchi sp. Memories are of abundant macrofauna, including foxes, wolves, black bears, red pandas, and several species of small deer.

Pastures and watercourses

Livestock was the main indicator of wealth and a primary indicator of prestige in traditional Nuosu society. Pasturelands were held in common, and there were few regulations about which animals could graze where. The valley floor of Apiladda supported an open riparian forest suitable for pasturing animals and composed of mixed hardwood species (a 1968 satellite image shows that this forest still present; Fig. 9). Elders report that in the 1950s, the main stream on the floor of Apiladda flowed in a single channel, with less seasonal or storm-related flow variation than today. 
Table 2. Qualitatve assessment of adherence to Ostrom's (1990) eight design principles, based on oral interviews and field observations.

\begin{tabular}{|c|c|c|c|c|c|c|c|c|}
\hline \multirow[b]{2}{*}{$\begin{array}{l}\text { Cycle and } \\
\text { phase }\end{array}$} & \multicolumn{8}{|c|}{ Principle } \\
\hline & $\begin{array}{c}1 . \\
\text { Clear } \\
\text { boundaries }\end{array}$ & $\begin{array}{l}2 . \\
\text { Congruent } \\
\text { rules }\end{array}$ & $\begin{array}{c}3 . \\
\text { Collective } \\
\text { choice }\end{array}$ & $\begin{array}{c}4 . \\
\text { Monitoring }\end{array}$ & $\begin{array}{c}5 . \\
\text { Graduated } \\
\text { sanctions }\end{array}$ & $\begin{array}{c}6 . \\
\text { Conflict } \\
\text { resolution }\end{array}$ & $\begin{array}{l}7 . \\
\text { Right to } \\
\text { organize }\end{array}$ & $\begin{array}{c}8 . \\
\text { Nested } \\
\text { enterprises }\end{array}$ \\
\hline $\begin{array}{l}\text { I: r, 1920- } \\
1956\end{array}$ & $\begin{array}{l}\text { Partially } \\
\text { supported }\end{array}$ & Supported & Supported & Unknown & Supported & Supported & Supported & $\begin{array}{c}\text { Not } \\
\text { applicable }\end{array}$ \\
\hline $\begin{array}{l}\text { I-II: } \Omega \alpha \\
1957-1961\end{array}$ & Violated & Violated & Violated & Violated & Violated & Violated & Violated & Violated \\
\hline $\begin{array}{l}\text { II: r-K, } \\
1961-1983\end{array}$ & $\begin{array}{l}\text { Partially } \\
\text { supported }\end{array}$ & Violated & Violated & Violated & Violated & Violated & Violated & Violated \\
\hline $\begin{array}{l}\text { II: K-K, } \\
\text { 1983-2008 }\end{array}$ & $\begin{array}{l}\text { Partially } \\
\text { supported }\end{array}$ & Violated & Violated & $\begin{array}{c}\text { Partially } \\
\text { supported }\end{array}$ & Violated & $\begin{array}{l}\text { Partially } \\
\text { supported }\end{array}$ & Violated & Violated \\
\hline
\end{tabular}

\section{Institutions}

During this period, institutions were controlled by the resource users, with little or no interference from higher organizations. Decisions about forest use were made at the family level and informed by TEK, leading to a diversity of resource management strategies. Each extended family owned rights to forest resources extending from its house to the top of the nearest ridge. Other families could take wood with permission, but all were constrained in their use of forest resources by a series of regulations and taboos, most notably against cutting down trees or shooting wild animals during the growing season from the time the first rhododendrons flowered in spring until the final oat harvest in fall. Similarly, Nuosu TEK draws an explicit parallel between the productivity of the ecosystem and the kinship system. The relationship between trees and rivers allows the water to flow clean and not erode the stream banks, thus preserving the productivity of the ecosystem. In parallel fashion, the relationship between the wife's clan and the husband's allows children to be born, thus preserving the social system.

Institutions were in line with many of Ostrom's (1990) design principles (Table 2). In-depth knowledge about the ecosystem structures and functions was embedded within local customary laws guiding forest resource use, suggesting congruence with principle 2. Boundaries were clearly defined, with individual families managing the forests behind their homes and more distant forests managed collectively, congruent with principle 1. Conflicts were resolved by appeal to respected mediators known as ndeggu and backed by agreement among clan leaders, congruent with principles 5 and 6 . There were high levels of local autonomy and strong local control over resource decisions, congruent with principle 5. In this situation, the participation of local members in rule setting and enforcement was likely to have contributed to the resilience of the social-ecological system as a whole.

This set of institutions changed dramatically after 1956, when disturbances originating at higher levels threw the system into a rapid release $(\Omega)$ phase.

\section{Cycle I-II, $\Omega-\alpha$, 1957-1961: a rapid flip in response to disturbance}

\section{Resource users and institutions}

In 1956, the Chinese Communist Party began a program of radical social revolution in ethnic minority regions, known as the Democratic Reforms. In Nuosu areas, this meant the abolition 
Table 3. Timeline of ecological and political change in the Upper Baiwu watershed, 1920-2008. Historical dates are aligned with phases in the adaptive cycle.

\begin{tabular}{|c|c|c|c|c|c|c|}
\hline $\begin{array}{l}\text { Cycle and } \\
\text { phase }\end{array}$ & Norm-setters & $\begin{array}{l}\text { Scale of norm- } \\
\text { setting }\end{array}$ & Goals & $\begin{array}{l}\text { Enforcement } \\
\text { mechanisms }\end{array}$ & Major events & $\begin{array}{c}\text { Adherence to } \\
\text { principles } \dagger\end{array}$ \\
\hline $\begin{array}{l}\text { I: r, 1920- } \\
1956\end{array}$ & Community & Local & $\begin{array}{l}\text { Sustainable } \\
\text { resource use }\end{array}$ & $\begin{array}{l}\text { Ritual, formal } \\
\text { mediators, } \\
\text { community } \\
\text { sanctions }\end{array}$ & $\begin{array}{l}\text { Nuosu move to } \\
\text { lowlands; slow } \\
\text { expansion }\end{array}$ & Supported \\
\hline $\begin{array}{l}\text { I-II: } \Omega-\alpha, \\
1957-1961\end{array}$ & $\begin{array}{l}\text { Communist } \\
\text { Party }\end{array}$ & National & $\begin{array}{l}\text { Maximum } \\
\text { resource } \\
\text { extraction; } \\
\text { transformation }\end{array}$ & $\begin{array}{l}\text { Propaganda, } \\
\text { class struggle }\end{array}$ & $\begin{array}{l}\text { Great leap } \\
\text { forward; village } \\
\text { nucleation; } \\
\text { large-scale } \\
\text { cutting }\end{array}$ & Violated \\
\hline $\begin{array}{l}\text { II: r-K, 1961- } \\
1983\end{array}$ & $\begin{array}{l}\text { Communist } \\
\text { Party }\end{array}$ & National & $\begin{array}{l}\text { Maximum } \\
\text { resource } \\
\text { extraction; } \\
\text { development }\end{array}$ & $\begin{array}{l}\text { Propaganda, } \\
\text { class struggle }\end{array}$ & $\begin{array}{l}\text { Collective } \\
\text { agriculture; } \\
\text { large-scale } \\
\text { cutting }\end{array}$ & Violated \\
\hline $\begin{array}{l}\text { II: K-K, } \\
\text { 1983-2008 }\end{array}$ & $\begin{array}{l}\text { Communist } \\
\text { Party, } \\
\text { technocrats }\end{array}$ & $\begin{array}{l}\text { National and } \\
\text { local }\end{array}$ & $\begin{array}{l}\text { Development; } \\
\text { preservation }\end{array}$ & Policing & $\begin{array}{l}\text { Economic } \\
\text { development; } \\
\text { conservation } \\
\text { programs }\end{array}$ & Violated \\
\hline $\begin{array}{l}\text { III: } \Omega-\alpha, \\
\text { (possible } \\
\text { future) }\end{array}$ & $\begin{array}{l}\text { Communist } \\
\text { Party, } \\
\text { contractors, } \\
\text { possibly } \\
\text { community }\end{array}$ & $\begin{array}{l}\text { National and } \\
\text { local }\end{array}$ & $\begin{array}{c}\text { Preservation; } \\
\text { profit }\end{array}$ & Policing & $\begin{array}{l}\text { Privatization of } \\
\text { forests; } \\
\text { classification of } \\
\text { forests }\end{array}$ & Unknown \\
\hline
\end{tabular}

$†$ Adherence to Ostrom's (1990) design principles reflects a qualitative assessment of support or violation of each of the eight principles (see Table 2).

of slavery and other forms of caste subordination and servitude. This provoked a guerilla rebellion led primarily by aristocrats. Fearing that a population living in scattered compounds would be difficult to control, and to prepare for nation-wide agricultural and economic collectivization, the regime instituted a program called residential concentration points, or jumin dian, which moved inhabitants of the Upper Baiwu into the concentrated villages of Yangjuan and Pianshui. Not long afterwards, the nationwide development scheme known as the Great Leap Forward attempted to achieve rapid economic development through short-term increases in resource extraction (Yang 1996, Smil 1999, Shapiro 2001). Agriculture was first reorganized as collective farms, and by 1958 , all production was communized. All property was held in common, labor was communally organized, and resource decisions were severely constrained by national imperatives. The results of these dramatic disturbances included immediate social chaos and starvation. Eight people in Yangjuan and at least 20 people in Pianshui starved to death or died of malnutrition-related diseases.

After two years, the communist system was once again modified. A Baiwu Production Brigade was organized into eight production teams, each responsible for its collective fields. These teams were the precursors of today's Villager Small Groups. People were paid for agricultural labor in work points, and the number of points earned by a household determined the distribution of collective grain to that household. Pig and sheep production 
Fig. 7. The panarchy metaphor illustrates system dynamics and cross-scale interactions in the Upper Baiwu watershed over time. The illustration shows one scale above (national) and below (family or collective) the system of interest. Cycle I exhibits loose connections with national socioeconomic policy. Community traditions set norms based on strong feedbacks between local family and watershed system scales. Cycle II depicts the system after the National Democratic Reforms in 1957 and continuing to the present day. Strong national controls dictate local resource use, leading to a scale mismatch and diminished feedbacks between lower scales. After 1957, the collective replaces the family as the smallest scale within the interaction hierarchy. Cycle III begins in 2008 with the new forest use policy. The desirable scenario is characterized by greater feedbacks among all three scales of organization. National forest policies are decentralized to reflect the information and needs transmitted from lower scales. Strengthened local institutions and cooperative relationships between the state and local communities could enable communities to respond directly to changes in the watershed through the development of a monitoring system for adaptive and sustainable forest management.

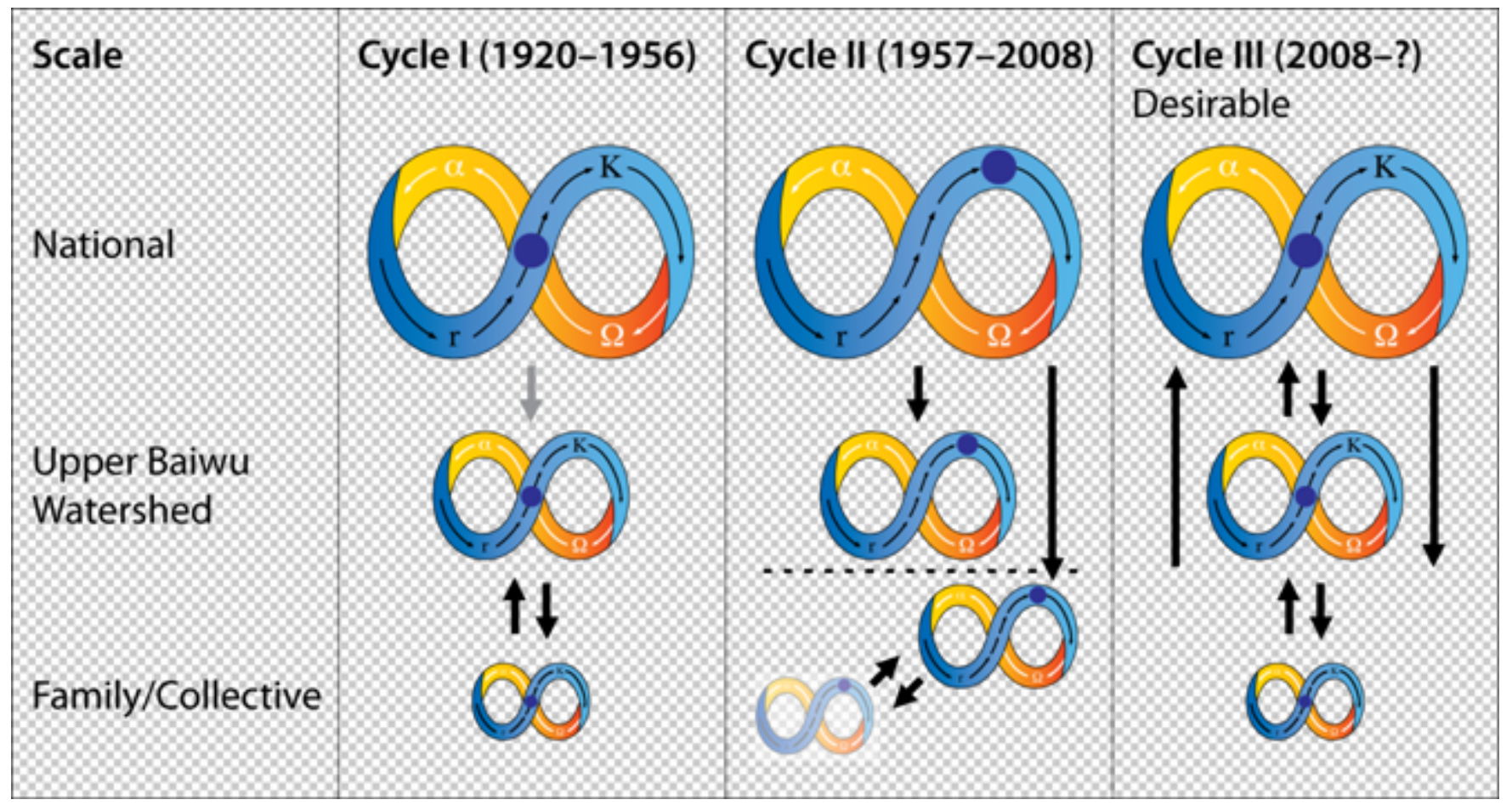

were also collectivized and assigned to small groups of households in Zhuchang and Gangou, respectively.

The revolutionary changes of 1957-1961 thus changed the level of resource management from the family to the collective, or production team. Regulations regarding what crops to plant and where, what livestock to raise and where to graze it, and which forests should be cut for what uses were transmitted from higher governmental levels through the commune and brigade without feedback from lower social and ecological scales. This deprived resource users of the ability to manage and monitor their own resource use (Fig. 7). During this period, historical local and informal institutions were effectively dismantled. This transition resulted in the violation of Ostrom's (1990) principles 2, 3, 5 , and 6 (Table 2), reflecting a mismatch between the scale at which norms for resource management were set and the scale of dynamics among local resources and resource users. 
Fig. 8. A summary of key changes in institutions, resources, and resource users within the Upper Baiwu watershed across two adaptive cycles (1920-2008).

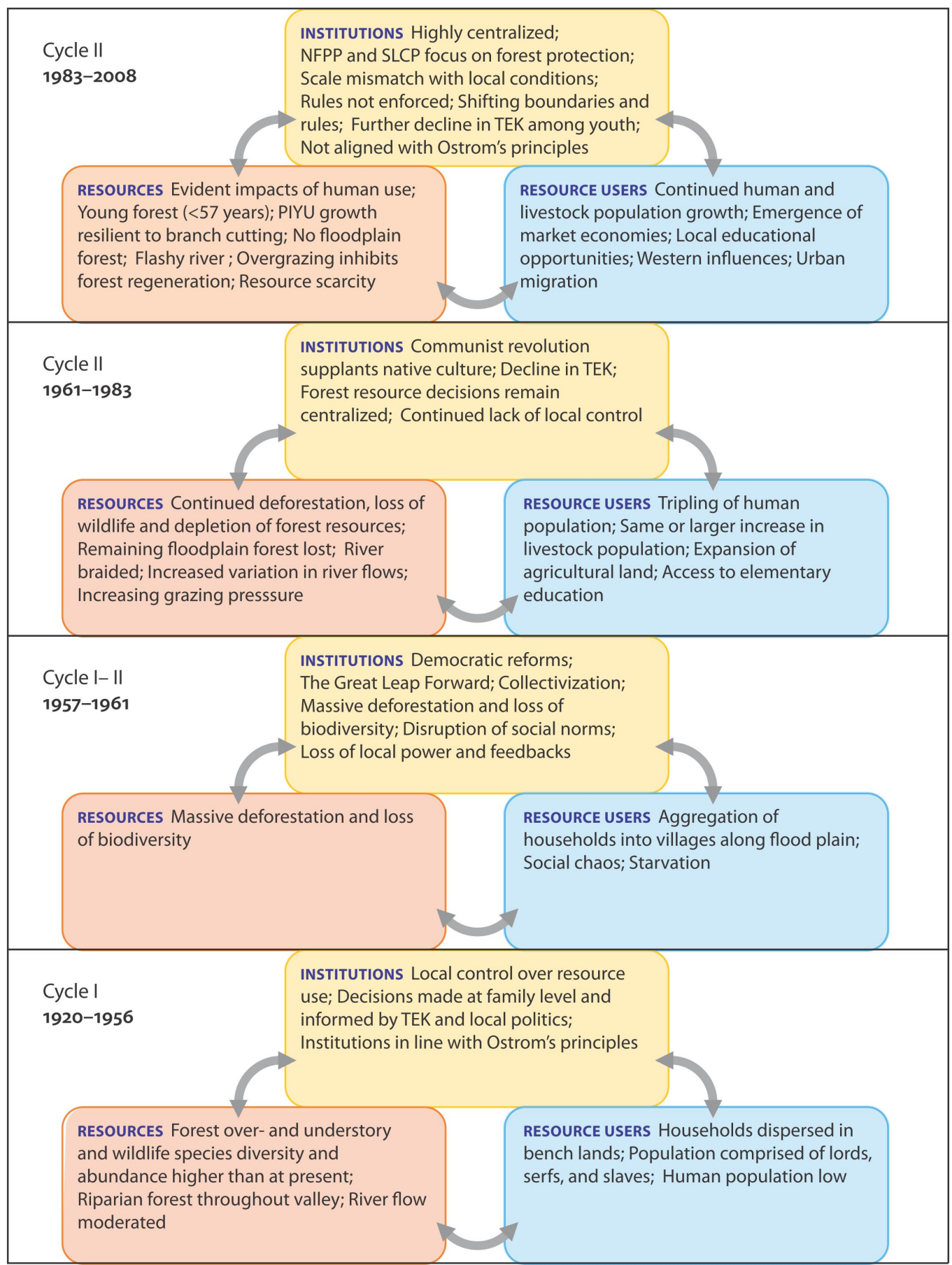


Fig. 9. United States Air Force Corona satellite image of part of the Upper Baiwu watershed in 1968. Note the extensive cutting in the mixed forest area in the western part of the Apiladda watershed, sparse vegetation in the benchlands, and gallery forests in the Apiladda floodplain.

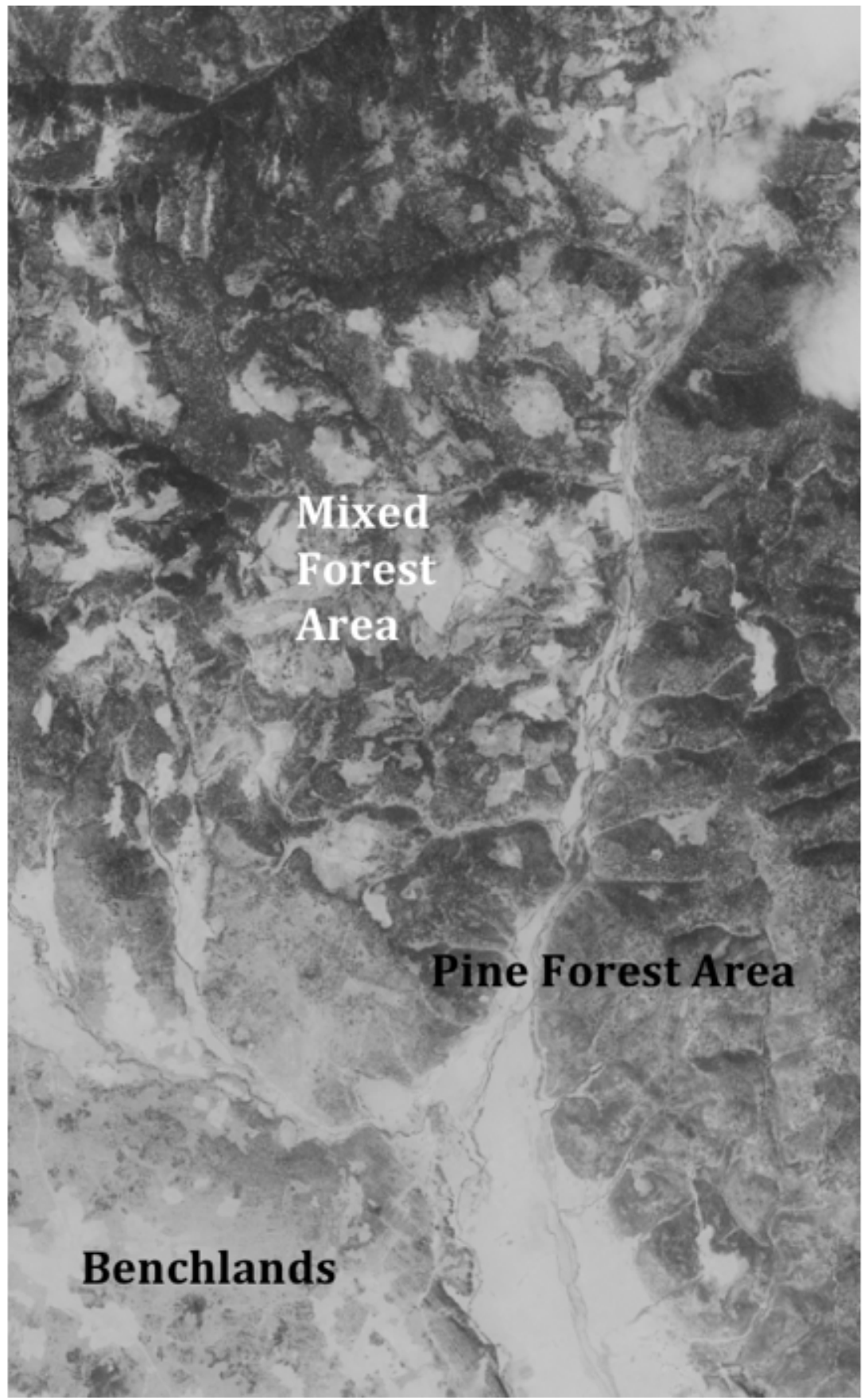




\section{Resources}

Forests

National revolutionary and developmental policies had direct and immediate effects on forest cover. Remaining forests on the benchlands were removed to expand agricultural production: the oak and juniper forests located between Yangjuan, the hills to the west, and the benchlands were denuded to fuel kilns manufacturing lime for house construction; the mixed, oak-dominant forests on the lower slopes between Yangjuan and Apiladda were cut to fuel kilns for tiles to roof new houses.

\section{Pastures and watercourses}

It is not possible to determine exactly what happened to the pastures during this time or whether there were immediate effects of collectivization of animal husbandry.

\section{Cycle II, r-K, 1961-1983: decreased resilience through slow variable change}

\section{Resource users}

After 1961, the Upper Baiwu system persisted in an alternative regime. Forest resource decisions remained centralized, the human population remained concentrated, and until 1983, agriculture and animal husbandry remained collectivized. The years between 1961 and 1983 represent the transition from the $r$ to $K$ phase of a second adaptive cycle, characterized by a combination of slow variable change (Gunderson 2003) and a series of small to moderate disturbances. Slow variables included a tripling of the human population, expansion of agricultural land, and the gradual loss of TEK. Many residents obtained access to elementary education, and the first community members went on to secondary school.

\section{Resources}

Forests

This was a period of intermittent deforestation. After 1968, much of the lower part of the floor of Apiladda was turned into farmland. The floodplain forests were eliminated by 1986, and there was extensive cutting on lower slopes adjacent to the Apiladda floodplain, in the pine forest in Laizigou, and on some of the side valleys. According to the accounts of elders, people began to travel farther in search of firewood. People also report that wild mammals and birds became scarcer at this time.

\section{Pastures and watercourses}

According to local people, the Gangou stream began to assume its current form in the lower reaches by the mid-1970s: braided channels, a rapidly migrating main stem, wide seasonal variations in flow, and a heavy sediment load during periods of high discharge. Local people attribute this to a combination of upstream cutting and clearing of the riverine forests on the valley floor. Increased numbers of livestock accompanying human population increase also put heavier pressure on pastures.

\section{Institutions}

This period began with the political struggles leading up to the Cultural Revolution, which included not only the class struggles that took place in majority Han areas of China, but also the struggles against "backward ethnic customs" that were peculiar to minority areas such as the Baiwu Valley. Community member Mgebbu Lunzy (Mgebbu 2003:143) describes this process vividly:
From the beginning of the Cultural Revolution, the local government had made everything to do with Nuosu traditional culture and customs into targets for reform, emphasizing wearing Han-style clothes, cooking on a stove, making dry land into paddy fields... Nuosu people, though they dared not oppose openly, still secretly all said the Han policy was really strange: a people has its own lifestyle customs, why do we have to do everything the same way the Han do it?

A local elementary school in Baiwu Town, founded in the late 1950s, is an example of what Mgebbu Lunzy describes as local government reform. Students were taught only in Chinese, and the ideas of the Communist revolution began to displace or at least call into question the ideas of native cultures. This was the beginning of local people's loss of TEK.

During this period, there was continued lack of local control over resource management. Local 
ecological knowledge did not have an opportunity to adapt with changing socio-political and ecological conditions. Thus, the system was maintained in a state in which sustainable local resource management was not able to develop, marking a reinforced and enhanced departure from Ostrom's (1990) design principles (Table 2).

\section{Cycle II, K-K, 1983-2008}

\section{Resource users}

Four significant disturbances brought about accelerated cultural change during the past few decades. First, the founding of the Yangjuan Primary School in 2000 provided opportunities for more children to be educated than ever before. Second, coinciding with the school, Yangjuan became more open, making it easier for anthropologists, ecologists, and others to carry out research. Third, exposure to media increased; in particular, television was found in approximately $60 \%$ of Yangjuan homes in a 2008 survey. Finally, labor migration to nearby towns and cities (Pun 2005, Chan 2009) gave families a source of income, exposed them more directly to mainstream Chinese and world globalized cultures, and gave them increased cash incomes, enabling slow growth in consumption levels of both food and consumer goods. Local population growth has slowed since the 1990s establishment of China's Planned Birth Program, which restricts members of ethnic minorities to three children.

\section{Resources}

\section{Forests}

Continued pressure on forests for litter, branches, firewood, and construction materials brought this resource subsystem to its current state. Villagers report the need to travel farther to gather firewood. Despite the logging ban imposed by the NFPP, we observed considerable large tree removal, e.g., freshly cut stumps, downed logs, and logs being carried from the forest. In the early 1980 s, forests above Gangou (Fig. 2) were logged by state logging companies.

In balance, the history of the forests since the early 1980s has been a tug-of-war between the everyday demands of a slowly growing population and efforts to preserve or rehabilitate forest resources.
Preservation efforts have taken several forms. Within the local community, three village families obtained lease contracts on patches of pine forest covering hills behind Pianshui and have attempted to manage these lands for conservation. As a result, the stands are noticeably denser than adjacent stands. Attempts to reforest some previously cleared areas through the NFPP and SLCP programs exhibit mixed results. These efforts often fail because of a combination of unsuitable species selection, livestock overgrazing, and poor program management (Weyerhauser et al. 2005, Trac et al. 2007).

\section{Pastures and watercourses}

Although riparian forest cutting has ceased, trees have not been regenerating, an example of hysteresis in which the subsystem of the valley floor has changed its controlling variables. Livestock appear to graze and trample any seedlings that germinate. In spring 2008, the county government promoted an initiative to fence out livestock and reforest the lower alluvial plain of the Apiladda Valley with Populus spp. to stabilize the watercourse and provide additional supplies of nowscarce firewood. Although several fences around these plantations were breached by humans and livestock, the plantings exhibit high survival and growth rates. The program received enthusiastic support from some local families, but there are potential conflicts with pig owners because the pigs root out some of the saplings.

\section{Institutions}

Deng Xiaoping's reforms have transformed China's economy and society to a degree perhaps even greater than the changes brought about by Mao's revolution. The first large-scale social change in this area was the decollectivization of agriculture and livestock in 1983. Once again, the family became the relevant level of agricultural decision making. Forests and pastures, however, remain collective property, and regulations for their use continue to be set by managers at higher scales. The decollectivization of agriculture was accompanied by several attempts to cultivate a series of cash crops, including apples, hybrid corn, Sichuan peppercorn, walnuts, and sunflowers. There is also an occasional market for pigs and sheep products, and a few villagers have begun to raise yaks commercially in the high-altitude pastures of the Zala mountains (Abby Lunstrum, unpublished 
data). Most of these programs have been initiated from scales above that of the watershed and the village community.

China's move into global markets, the associated need to meet international environmental standards, and increased awareness of the socioeconomic effects of environmental degradation resulted in a national-level policy shift toward forest conservation, as exhibited with the NFPP and SLCP. However, as documented in other areas of southwest China, indigenous people are rarely included in management decisions (Xu and Melick 2007). The gap between national regulations and local needs has resulted in a breakdown of rules and the potential exacerbation of environmental effects, and may have impeded the development of local institutions for resource use that reflect contemporary socialecological conditions (Weyerhaeuser et al. 2005, Trac et al. 2007, Xu and Melick 2007).

\section{Historical summary}

We have summarized the state of resources, resource users, and institutions in the Upper Baiwu Valley since the 1920s (Fig. 8), as well as the degree of institutional compliance with Ostrom's (1990) design principles (Table 2). With the newly promulgated CFR forest policy, the communities of the Upper Baiwu Valley find themselves at a crossroads. With reduced resources, a concentrated population, and increased influence from external forces, villagers seek guidance on how to develop sustainable and resilient forest practices. Although it is impossible to return to pre-Maoist conditions, understanding the historic drivers of system change in the watershed is critical to judge the degree to which projections of future patterns can be drawn from the past. We next assess the watershed's current state in light of past lessons and future opportunities to strengthen local institutions for governance of forest resources.

\section{DISCUSSION AND CONCLUSION}

The current state of the Upper Baiwu socialecological system reflects a legacy of past responses to institutional disturbances initiated at the larger, national, system scale. Beginning with the so-called Communist Democratic Reforms in 1957 and continuing through the NFPP and SLCP, centralized forest regulations have imposed a mismatch between the scale of management and the scale of the ecological processes being managed (Cumming et al. 2006). As documented in other minority communities of southwest China, these policies have inhibited traditional resource use in the watershed and undermined local common property institutions (Sturgeon 2005, Harwood 2009), though in some areas, there has been partial return to local control since the 1980 s, something not clearly seen in the Upper Baiwu (Sturgeon 2005). In 2008-2009, we find the Upper Baiwu Valley to be in a highly vulnerable state. However, our analysis also reveals elements of the resource and resource user subsystems that signify a level of adaptive capacity and resilience. These factors offer opportunities to strengthen local capacity for the development of a sustainable system of forest use. We think that whether these opportunities can be realized depends on how the institutions within and beyond the local community evolve in the current situation of rapidly changing policies.

The CFR policy seeks to devolve some control over resource management back into the hands of local communities. Collective forest users will now be allowed to manage commodity forests for profit through the transfer of long-term leases to private contractors. This policy shift may present a critical juncture between single-purpose management for short-term economic gains and the development of a system for local sustainable resource use. How the social-ecological system responds to this opportunity will depend on local preferences and the extent to which local adaptive capacity, exhibited through memory, creativity, innovation, flexibility, and diversity of ecological components and human capabilities (Walker et al. 2002), persists in the system's current state.

Within the resource subsystem, $P$. yunnanensis exhibits the capacity to maintain good growth following extensive branch cutting. This trait may confer resilience in the watershed's capacity to provide the firewood and construction materials required to meet community needs despite high levels of resource use. Additionally, the recent restoration efforts to fence off floodplain areas from grazing and propagate poplar trees indicate local human interest in and capacity to manage and improve their resources.

The resource user subsystem also exhibits elements of adaptability and resilience. The community's refusal to accept recent single-purpose, profit- 
driven contractor bids suggests an interest in developing more sustainable practices. Also, strong social and ecological memory of local TEK persists within older generations, and these elders are still respected as leaders. We have held several meetings attended by elders and younger people with more formal education at which they have requested us to formulate a comprehensive ecological restoration plan for them to consult as they move forward in their efforts. The establishment of the Yangjuan Primary School in 2000 offers an opportunity to pass local TEK to younger generations at the same time that they are receiving education in more modern scientific ideas of conservation.

Still, the desires of local people and outside scientists to collaborate in planning and restoration are threatened by the continuing hesitancy of planners and bureaucrats to restore meaningful community control over resource planning and management. Switching from top-down planning to private enterprise management for profit, as appears to be the intent of the current policy shift, runs the danger of leaving the community out of the decision-making process. Working to establish or re-establish community-based institutions in accordance with Ostrom's (1990) principles would go a long way toward meeting the goal of socialecological resilience and sustainability.

Responses to this article can be read online at: http://www.ecologyandsociety.org/volXX/issYY/artZZ/ responses/

\section{Acknowledgments:}

Funding was provided by the National Science Foundation's Program in Integrative Graduate Education and Research Training (0333408), the College of Forest Resources at the University of Washington, University of Washington-Sichuan University Exchange Program, and the University of Washington China Studies Program. A. C. Henck was funded by an NSF graduate research fellowship. We thank many residents of the Baiwu watershed who shared time, knowledge, and ideas over the years, in particular Hxiesse Vuga, Lurlur Adda, Ma Vuga, Ma Fagen, Mgebbu Ashy, and Ma Lunzy. Invaluable assistance with fieldwork in summer 2008 came from our Sichuan University colleague Professor Zeng Zongyong and his students Liu Yingqi and Liu Lang, Michelle Haynes (University of Wisconsin, Madison), He Yanni, and Laura Stahl. In fall 2008, Porter Teegarden and Lenka Stafl provided geomorphological fieldwork assistance. Finally, we are especially indebted to Matt Dunbar of the Center for Studies in Demography and Ecology, University of Washington, for his help with all matters of GIS arcana.

\section{LITERATURE CITED}

Abbe, T. B., and D. R. Montgomery. 1996. Large woody debris jams, channel hydraulics and habitat formation in large rivers. Regulated Rivers: Research \& Management 12(2-3):201-221.

Abel, T. 2006. World-systems as complex human ecosystems. Pages 56-73 in A. Hornborg and C. L. Crumley, editors. The world system and the earth system: global socioenvironmental change and sustainability since the neolithic. Left Coast Press, Walnut Creek, California, USA.

Agrawal, A. 2001. Common property institutions and sustainable governance of resouces. World Development 29(10):1649-1672.

Anderies, J. M., M. A. Janssen, and E. Ostrom. 2004. A framework to analyze the robustness of social-ecological systems from an institutional perspective. Ecology and Society 9(1): 18. [online] URL: http://www.ecologyandsociety.org/vol9/iss1/ $\underline{\operatorname{art} 18 .}$.

Chan, K. W. 2009. Population, migration and the Lewis Turning Point in China. Pages 119-151 in C. Fang and D. Yang, editors. The China population and labor yearbook, volume 1: the approaching Lewis Turning Point and its policy implications. Brill, Leiden, The Netherlands.

Chi, P. M. 2004. Human disturbance and biomass growth in Upper Baiwu pine forests. Undergraduate thesis. University of Washington, Seattle, USA.

Cumming, G. S., D. H. M. Cumming, and C. L. Redman. 2006. Scale mismatches in socialecological systems: causes, consequences, and solutions. Ecology and Society 11(1): 14. [online] URL: http://www.ecologyandsociety.org/vol11/iss1/ $\underline{\operatorname{art} 14 .}$. 
Dai, L., F. Zhao, G. Shao, L. Zhou, and L. Tang. 2009. China's classification-based forest management: procedures, problems, and prospects. Environmental Management 43(6):1162-1173.

Gunderson, L. H. 2003. Adaptive dancing: interactions between social resilience and ecological crises. Pages 33-52 in F. Berkes, J. Colding, and C. Folke, editors. Navigating socialecological systems: building resilience for complexity and change. Cambridge University Press, Cambridge, UK.

Harrell, S. 2001. Ways of being ethnic in southwest China. University of Washington Press, Seattle, Washington, USA.

Harwood, R. E. 2009. Negotiating modernity at China's periphery: an investigation of development and policy interventions in Nujiang Prefecture. Dissertation. University of Western Austrailia, Perth, Australia.

Hill, A. M. 2001. Captives, kin, and slaves in Xiao Liangshan. Journal of Asian Studies 60 (4):1033-1049.

Hoang, C. 2009. Forest thieves? The politics of forest resources in a northwestern frontier valley of Vietnam. Dissertation. University of Washington, Seattle, Washington, USA.

Hyde, W. F., B. Belcher, and J. Xu. 2003. China's forests: global lessons from market reforms. Resources for the Future, Washington, D.C., USA.

Jarvis, D., and H. Liu. 1993. Vegetation patterns in the Pinus yunnanensis-sclerophyllous broadleaved forests, Mianning County, Sichuan Province, China. Journal of Biogeography 20:505-524.

Levin, S. A., S. Barrett, S. Aniyar, W. Baumol, C. Bliss, B. Bolin, P. Dasgupta, P. Ehrlich, C. Folke, I.-M. Gren, C. S. Holling, A. Jansson, B.-O. Jansson, K.-G. Mäler, D. Martin, C. Perrings, and E. Sheshinski. 1998. Reslience in natural and socioeconomic systems. Environment and Development Economics 3(2):221-262.

Li, X., and D. Walker. 1986. The plant geography of Yunnan Province, southwest China. Journal of Biogeography 13:376-397.
Liu, J. 2009. Implications and challenges of decentralized China's collective forest management. In Proceedings of the XIII World Forestry Congress (Buenos Aires, October 2009). Food and Agriculture Organization, Rome, Italy. [online] URL: http://www.cfm2009.org/es/programapost/trabajos/ Implications FD.pdf.

Liu, J., T. Dietz, S. R. Carpenter, M. Alberti, C. Folke, E. Moran, A. N. Pell, P. Deadman, T. Kratz, J. Lubchenco, E. Ostrom, Z. Ouyang, W. Provencher, C. L. Redman, S. H. Schneider, and W. W. Taylor. 2007. Complexity of coupled human and natural systems. Science 317(5844):1513-1516.

Melick, D., X. Yang, and J. Xu. 2007. Seeing the wood for the trees: how conservation policies can place greater pressure on village forests in southwest China. Biodiversity and Conservation 16 (6):1959-1971.

Mgebbu, L. (Ma E). 2003. Nuosu and neighboring ethnic groups: ethnic groups and ethnic relations in the eyes and ears of three generations of the Mgebbu Clan. [Translated by S. Harrell] Asian Ethnicity 4 (1):129-144.

Miao, G., and R.A. West. 2004. Chinese collective forestlands: contributions and constraints. International Forestry Review 6(3-4):282-296.

Ostrom, E. 1990. Governing the commons: the evolution of institutions for collective action. Cambridge University Press, Cambridge, UK.

Pun, N. 2005. Made in China: women factory workers in a global workplace. Duke University Press, Durham, North Carolina, USA.

Scheffer, M., F. Westley, W. A. Brock, and M. Holmgren. 2002. Dynamic interaction of societies and ecosystems-linking theories from ecology, economy, and sociology. Pages 195-240 in L. H. Gunderson and C. S. Holling, editors. Panarchy: understanding transformations in human and natural systems. Island Press, Washington, D.C., USA.

Shapiro, J. 2001. Mao's war against nature: politics and the environment in Revolutionary China. Cambridge University Press, Cambridge, UK. 
Smil, V. 1999. China's great famine: 40 years later. British Medical Journal 319(7225):1619-1621.

Sturgeon, J. C. 2005. Border landscapes: the politics of Akha land use in China and Thailand. University of Washington Press, Seattle, Washington, USA.

Trac, C. J., S. Harrell, T. M. Hinckley, and A. C. Henck. 2007. Reforestation programs in southwest China: reported success, observed failure, and the reasons why. Journal of Mountain Science 4 (4):275-292.

United States Geological Survey. 1998. Declassified Intelligence satellite photographs: fact sheet 090-96 (February 1998). U.S. Geological Survey, Reston, Virginia, USA.

Walker, B., S. Carpenter, J. Anderies, N. Abel, G. S. Cumming, M. Janssen, L. Lebel, J. Norberg, G. D. Peterson, and R. Pritchard. 2002. Resilience management in social-ecological systems: a working hypothesis for a participatory approach. Conservation Ecology 6(1): 14. [online] URL: http://www.consecol.org/vol6/iss 1/art14/.

Weyerhaeuser, H., A. Wilkes, and F. Kahrl. 2005. Local impacts and responses to regional forest conservation and rehabilitation programs in China's northwest Yunnan Province. Agricultural Systems 85(3):234-253.

Xu, J., E. T. Ma, D. Tashi, Y. Fu, Z. Lu, and D. Melick. 2005. Integrating sacred knowledge for conservation: cultures and landscapes in southwest China. Ecology and Society 10(2): 7. [online] URL: http://www.ecologyandsociety.org/vol10/iss2/art7/

Xu, J., and D. R. Melick. 2007. Rethinking the effectiveness of public protected areas in southwestern China. Conservation Biology 21 (2):318-328.

Xu, J., and J. C. Ribot. 2004. Decentralisation and accountability in forest management: a case from Yunnan, southwest China. European Journal of Development Research 16(1):153-173.
Xu, J., R. Yin, Z. Li, and C. Liu. 2006. China's ecological rehabilitation: unprecedented efforts, dramatic impacts, and requisite policies. Ecological Economics 57(4):595-607.

Xu, Z., M. T. Bennett, R. Tao, and J. Xu. 2004. China's sloping land conversion programme four years on: current situation, pending issues. International Forestry Review 6(3-4):317-326.

Yang, D. L. 1996. Calamity and reform in China: state, rural society, and institutional change since the great leap famine. Stanford University Press, Stanford, California, USA.

Yanyuan County. 1984. [Gazetteer of place-names in Yanyuan County]. Yanyuan County Gazetteer Editorial Group, Yanyuan, Sichuan.

Zhang, P., G. Shao, G. Zhao, D. C. Le Master, G. R. Parker, J. B. Dunning, Jr., and Q. Li. 2000. China's forest policy for the 21 st century. Science 288(5474):2135-2136.

Zhonggong Zhongyang [Chinese Communist Party Central Committee]. 2008. Opinions of the Central Committee and the State Council regarding reforming the forestry rights system of collectively owned forests. [online] URL: http://www.gov.cn/jr zg/2008-07/14/content 1044403.htm. 